\title{
GROWTH AND COLOUR PERFORMANCE OF THE CROSSBREED MARBLE STRAIN Betta splendens AND Betta imbellis
}

\author{
Eni Kusrini, Riani Rahmawati, Siti Murniasih, Ruby Vidia Kusumah, and Anjang Bangun Prasetio \\ Research and Development Institute for Ornamental Fish
}

(Received 7 October 2014; Final revised 16 October 2015; Accepted 10 November 2015)

\begin{abstract}
Betta ornamental fish of marble strain is a strain which is prefered by the hobbyists, because of its unique color, expensive price, and difficult to obtain the fish color strains. Therefore strain marble betta fish is still dominant for export quality for national and international contests. The aim of this study was to observe the growth and color performance of the crossedbreed marble strains of wild betta, Betta imbellis crossed with Betta splendens. The hybrids of $B$. imbellis (o) $x$ B. splendens (o') (D) had a specific length and weight rate, $(1,113 \pm 0.04 \% /$ day; $2,531 \pm 0.14 \% /$ day; $26.61 \pm 2.02 \mathrm{~mm})$ which was better than that of the hybrids $B$. imbellis (o') x B. splendens (o) (C) (1,099 $\pm 0.02 \% /$ day; $2,244 \pm 0.13 \% /$ day; $25.97 \pm 1.33 \mathrm{~mm}$; and $0.0027 \pm$ $0.0003 \mathrm{~mm})$. However, the survival rate of the $C$ hybrids $(42.19 \pm 11.42 \%)$ was higher than those of $\mathrm{D}$ $(33.67 \%-17.08 \%)$. Based on the obtained results of the color identification the hybrids had as many as 15 characters of color, homozygous strains of marble which became the target of as much as $1 \%$.
\end{abstract}

KEYWORDS: wild betta, marble, crossbreeding

\section{INTRODUCTION}

Indonesian fisheries potential is huge, given the amount of water that reaches 5.8 million $\mathrm{km}^{2}$. The great potential should be supported by good management in order to accomplish the utilization of natural resources for Indonesian society. One of the potential that is now being developed is fishery sector particularly in ornamental fish. The export value of ornamental fish that is very promising in 2011 amounted to US\$ 13.262 million and up to US\$ 5.241 million April 2012 (Sakti, 2012).

The ornamental freshwater fish that have economic value and best sales on the market are Arowana (Scleropages formosus), Guppy (Poecilia reticulata), Koi (Cyprinus carpio), Betta (Betta sp.), and Rainbow (Melanonotaenia sp.) (Ipur, 2012). Betta fish (Betta sp.) are well-known as fighting fish that have beautiful fins and when it crosses, it can produce a new strain that has a higher price than that of its parent, and it is especially presented in contest or exibitions in national and international. Betta culture has well developed in many areas, because it is easy to handle and only requires little space in cultivation, so that it

\# Correspondence: Research and Development Institute for Ornamental Fish. Jl. Perikanan No. 13, Pancoran Mas, Depok 16436, Indonesia. Phone: + (021) 7520482

E-mail: ennyperikanan@yahoo.com is more efficient in utilization of narrow land. The central culture of betta can be found in many regions namely, Jakarta, Yogyakarta, Kediri, Banten, Semarang, and Bogor.

The types of existing ornamental betta are the results of the betta breeder since a decades ago. However, where the origin of the broodstock is not generally known, so it is hard to look for the original or the pure strains. It thereby occurs due to random, or uncontrolled matting so that the existing broodstock had experienced inbreeding for along time. Therefore, to trace the origins of a certain strains of broodstock was carried out by crossing of the wild betta.

Generally crossbreeding is performed to obtain new characters of broodstock which will combine and produce hybrid having a better appearance, resistant to diseases, and resistant to change of extreme environment (Hickling, 1968). The measurement of genetic diversity of hybridization can be conducted through the character of fenotype and genotype. The character of phenotype can be seen from morphology and the growth of tillers of crossbreeding results. By performing identification of color characters, the percentage of strains can be known for certain color. Identifications of Betta imbellis are difficult due to a lot of overlap with genuine wild-caught (or 
at least, wild-type, non-fancy) Betta splendens that had very similar colouration and fin lengths. However, males Betta imbellis typically have red edges to their fins and the green-blue colouration is distinctly stripy, on the gills, flanks, and unpaired fins. The aim of this study was to observe the growth and color performance of the crossedbreed marble strains of wild betta, Betta imbellis crossed with Betta splendens.

\section{MATERIALS AND METHODS}

The research was conducted in the Research and Development Institute for Ornamental Fish, at Depok. The size of the broodstock used on a cross of inter-strains and the pattern of a cross between $B$. imbellis (ㅇ) $\mathrm{x} B$. splendens $\left(\sigma^{*}\right)$, on the contrary $B$. imbellis $\left(\sigma^{\prime}\right) \times B$. splendens (o) are presented on Table 1. Parameters observed during the research were: broodstock condition, the pattern of spawning, fertilization, hatching rate, growth rate of the length and weight, survival rate, and character of color. The mating design with the three treatments and three replications was described in Table 2.

At least 11 months old of wild betta broodstocks were solitary maintained at a density one fish per tank (aquarium), measuring $20 \mathrm{~cm} \times 20 \mathrm{~cm} \times 15 \mathrm{~cm}$ and $\mathrm{pH}$ water about 5-6. The feed given to the fish was the larvae of Chironomus sp. and interspersed with the mosquito (Culex sp.) gave twice a day for ad libitum. Two cross patterns for data collection were performed three times as replication. Water quality monitoring was conducted once a month on the reservoir. The water change was done every once a week.

\section{Interstrain Crossbreeding}

Matured broodstock of male betta was characterized by the formation of foam, while the female brodstock was characterized by abdominal bulge and a brighter color. Spawning was done naturally using a tank with diameter of $40 \mathrm{~cm}$, water depth approximately $10-15 \mathrm{~cm}$. The matured female and the male were placed together in one tank and given a shelter in the form of water hyacinth or stereofoam pieces. The resulting from spawning looked float around the existing substrate on water surface. After spawning, the female was detached or removed from the tank to avoid of eating eggs. The male was maintained in spawning tank for several days due to natural character for maintaining their eggs. When all of eggs hatched, the male was lifted from a spawning tank.

\section{Larvae Rearing}

The hatching eggs which already turned to the larvae were not given any feed from the outside, because they still had yolk eggs until four days after hatching. The larvae were given feed of nauplii Artemia until 1 month age, then proceed with the feeding of Moina sp. until two months age. Furthermore the fish larvae were given the larvae of Chironomus sp. and musquito two times a day as ad libitum. The hybrids reared became a broodstock candidates approximately five months and they had stable color for identification of color and shape.

The sampling was carried out every month, it was begun since two months until six months of rearing. The larvae were firstly anasthized using phenoxyethanol with doses of $0.5 \mathrm{mg} / \mathrm{L}$, then weighed with a precision DJ302BH CHQ scales having 1,000 g/ $0,01 \mathrm{~g}$ and photographed with a Canon SLR EOS 550 D. Before weighting, the larvae were dried by rag (thessa). The pictured result was analyzed with "imageJ" software to get the data of measurement based on a resolution.

Table 1. Size of broodstock used for hybridization ( $\mathrm{N}=12$ ind.)

\begin{tabular}{|c|c|c|c|c|}
\hline \multirow{2}{*}{ Parental } & \multicolumn{2}{|c|}{ Male } & \multicolumn{2}{|c|}{ Female } \\
\hline & Body weight (g) & Total length $(\mathrm{cm})$ & Body weight (g) & Total length $(\mathrm{cm})$ \\
\hline$\sigma^{*} B$. imbellis $\mathrm{x} \odot B$. splendens & $1.04 \pm 0.54$ & $4.4 \pm 0.7$ & $1.16 \pm 0.38$ & $4.3 \pm 0.44$ \\
\hline$\sigma^{*} B$. splendens $\mathrm{x}$ ○ $B$. imbellis & $1.14 \pm 0.27$ & $4.5 \pm 0.36$ & $1.3 \pm 0.25$ & $4.43 \pm 0.42$ \\
\hline
\end{tabular}

Table 2. The mating design

\begin{tabular}{lcc}
\hline & B. splendens & B. imbellis \\
\hline B. imbellis & $\mathrm{B}$ & $\mathrm{A}$ \\
B. splendens & $\mathrm{D}$ & $\mathrm{C}$ \\
\hline
\end{tabular}


A selection of color and shape for a variation and color segregation were conducted at the stable color and five months old hybrids. Identification of color was done on some parts of segmented fish body namely: the tail fin, dorsal fin, anal fin, body, and a tie. All parts of identified color and percentage of closing on the surface as visual were scored from $0 \%$ $100 \%$.

\section{The Color Characteristics}

Descriptive color identification for the parts of the body, fins, and ties of each individual hybrid was done. The colors were adjusted to a standard observation Indo Betta Club by using a scoring percentage of color that covered parts measured. The results were further classified according to the percentage calculation of standard colors betta fish and colors of marble betta fish were used as the final outcome of the result of crossbreeding with $B$. imbellis the splendens.

\section{Data Analysis}

Variables were observed during the research including: growth of the length and weight of larvae and seed, number of fertilized eggs, total of eggs spawned, number of initial, and dead larvae. The characteristics of color with describing the parts of the body and fins, and color percentage. The color percentage of the body and the fins that cover were calculated based on the standard Indo Betta Club for each color percentage individual.

For the measurement of water quality was carried out once a month, with the parameters: temperature, $\mathrm{pH}, \mathrm{DO}, \mathrm{NH}_{3}, \mathrm{CO}_{2}$, alkalinity, hardness, and $\mathrm{NO}_{2}$. Absoulte growth rate counted using formula (Effendi, 1997):

$$
\Delta \mathrm{W}=\mathrm{Wt}-\mathrm{Wo}
$$

$\Delta \mathrm{W}=$ absolute growth rate

$\mathrm{Wt}=$ body weight at time $\mathrm{t}(\mathrm{g})$

Wo = initial body weight $-0(\mathrm{~g})$

The following was a formula of ferilization rate (FR):

$$
\mathrm{FR}=\frac{\text { The number of fertilized egg }}{\text { The total number of eggs spawned }} \times 100 \%
$$

Furthermore the degree of hatching (Hatching Rate/HR) was calculated by the formula:

$$
\mathrm{HR}=\frac{\text { The number of hatching eggs }}{\text { The number of fertilized eggs }} \times 100 \%
$$

While specific growth rate was calculated by the formula Castell \& Tiews (1980):

$$
\mathrm{SGR}=\frac{\operatorname{Ln} W \mathrm{t}-\operatorname{Ln} \mathrm{Wo}}{\mathrm{t}} \times 100 \%
$$

SGR = specific growth rate (\% weight of body/day)

$\mathrm{Wt}=$ weight at time $\mathrm{t}(\mathrm{g})$

$W_{0}=$ weight at time $0(\mathrm{~g})$

$\mathrm{t}=$ duration of research (day)

Mortality during maintenance is calculated based on the formula:

$$
M=\frac{\text { The number of dead larvae (fish) }}{\text { The number of initial larvae (fish) }}
$$

\section{RESULTS AND DISCUSSION}

Data of fertilization rate, hatching rate, and total larvae of spawning between $\sigma^{*} B$. imbellis $\mathrm{x}$ o $\quad B$. splendens and $o^{\circ} B$. splendens $\mathrm{x}$ o $B$. imbellis were presented in Table 3 . The number of larvae produced varied between $98-753$ of fish. The average fertilization rate of $C$ hybrids was $93.33 \%$ while D hybrids was $92 \%$. Betta splendens used were optimal broodstock for spawning; both of its parent's size and age, so that the results from crossing with Betta splendens produced a better larvae numbers than other treatments.

Several factors that affected the fertilization rate and the number of larvæ produced were derived from both internally and externally. The internal factors were the quality of broodstock and feed given for maintenance. While the external factors, were the environment and the season. At the optimal temperature and $\mathrm{pH}$, the larvæ were able slowly to adapt with their environmnet. According to Carrillo et al. (1989); Bromage et al. (1992); and Gillet (1994), environmental factors such as temperature, $\mathrm{pH}$, fotoperiod, and salinity on the cultivation media were able to affect the reproductive patterns and the quality of the resulting larvae.

\section{The Larvae Rearing of The Hybrids}

The results of the length and weight measurements of the hybrids showed a positive allometri pattern with a good correlation of $R$ value varied between 0.928-0.970 (Figure 1 and 2). The resulting hybrids of $\sigma$ B $B$. splendens $\mathrm{x} \propto \mathrm{B}$. imbellis had a better length and weight than the hybrids of $\sigma^{\prime} B$. imbellis $\mathrm{x} \rho B$. splendens.

Until the third month, the length of $\sigma^{\circ} B$. splendens $\mathrm{x}$ o $B$. imbellis hybrids were lower than that of the ơ $B$. imbellis $\mathrm{x} \odot B$. splendens hybrids, but after three months the length growth of ${ }^{\prime \prime} B$. splendens $\mathrm{x} q B$. imbellis hy- 
Table 3. Fertilization rate, hatching rate, and amount of larvae from crossing $(\mathrm{N}=3)$

\begin{tabular}{cccc}
\hline Crossing & Fertilization rate (\%) & Hatching rate (\%) & Total larvae (individual) \\
\hline$\sigma^{\prime} B$. imbellis $\times \circ B$. splendens & $93.3 \pm 5$ & $85.67 \pm 8.3$ & $557 \pm 298$ \\
$\sigma^{\prime} B$. splendens $\times \circ$ B. imbellis & $92 \pm 2$ & $90.18 \pm 7.63$ & $600.67 \pm 134.56$ \\
\hline
\end{tabular}

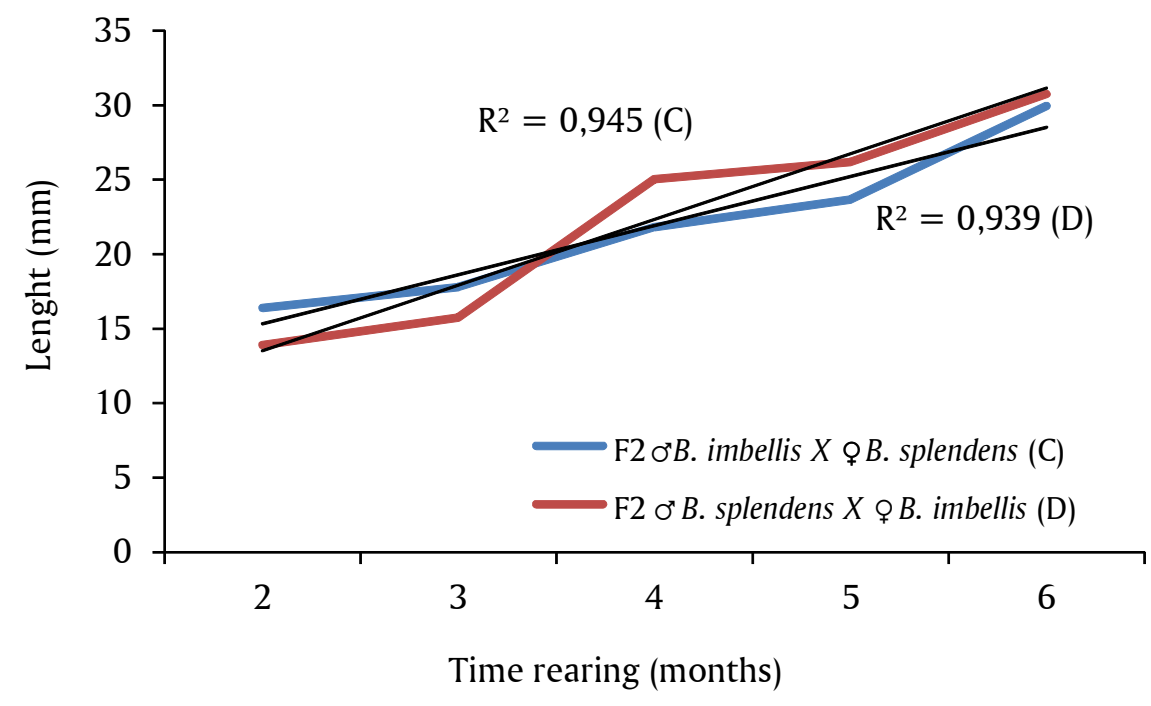

Figure 1. The length gain of crossbreed hybrid

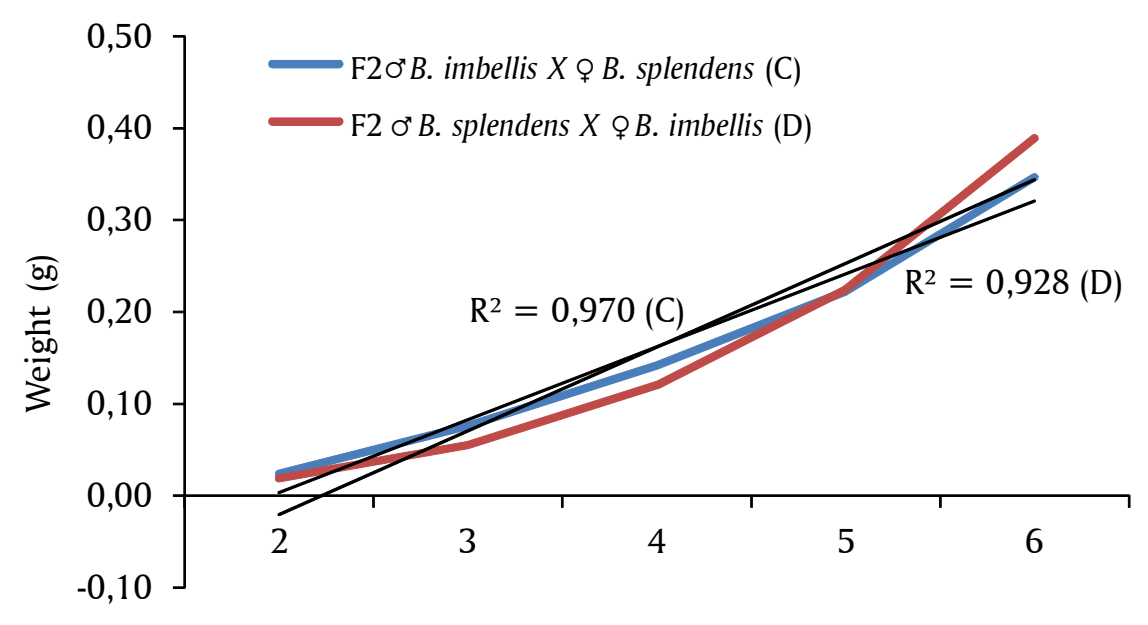

Time rearing (months)

Figure 2. The weight gain of F2 crossbreed

brids became faster than ${ }^{x} B$. imbellis $\mathrm{x} \propto B$. splendens. As well as for the weight gain of the o $B$. splendens $\mathrm{x}$ $\circ B$. imbellis hybrids became faster than ơ $B$. imbellis $\mathrm{x}$ o $B$. splendens after five month rearing. The increasing of weight of the hybrids was influenced by the efficiency of feed absorption that was more optimal on the suitable environment, so that the consumed feed was able to be well digested. l. Besides that the requirements and the types of feed depend on the larvae stage, the consumed feed would be changed into the energy for growth. However on the broodstock stage, the consumed feed was used much to gonadal maturation in reproduction process (Bromage et al., 1992).

The females broodstock of $B$. imbellis were estimated to have a dominant variation of length and weight gain, the result of the cross with the male of $B$. splendens had the higher growth. The female 


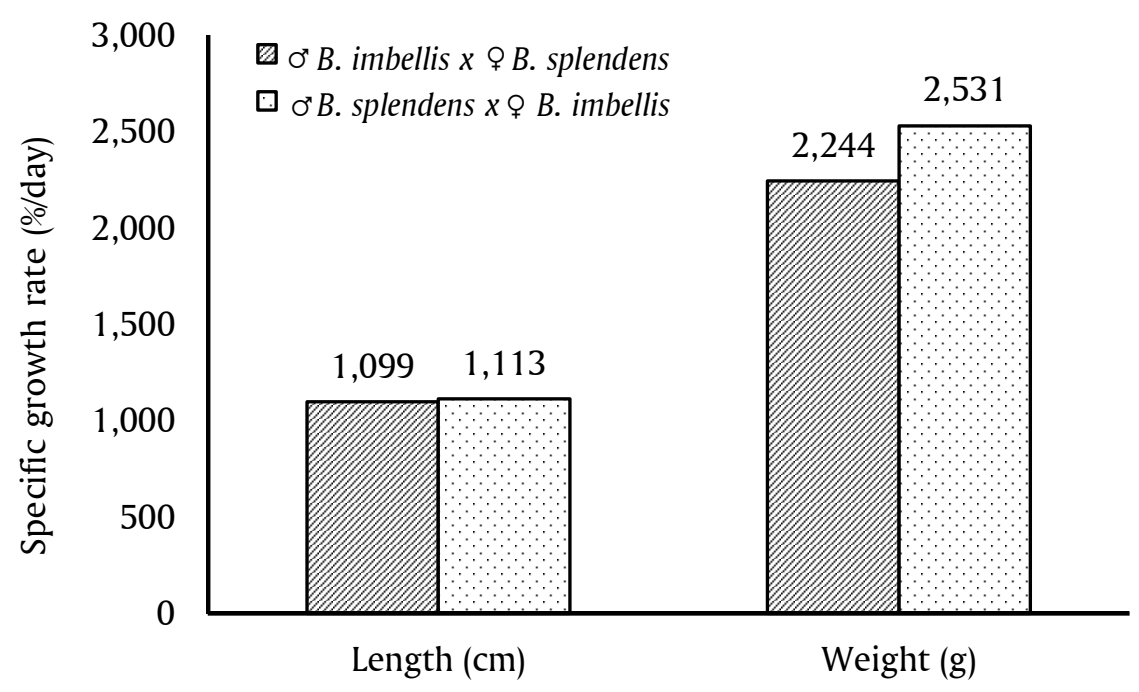

Figure 3. Specific growth rate (SGR) of hybrid

broodstock of $B$. imbellis giving an inheritance variation of length gains that were dominant on the seed compared with the male broodstock. According to Saavedra \& Amat (2005), that the maternal effect not only was caused by environment and genetic, but also the expression of several gen influenced by the environment.

At six month of rearing, SGR of weight was more dominant than SGR of length (Figure 3). The $O^{\prime} B$. imbellis $\mathrm{X} \odot B$. splendens hybrids had SGR of length and weigth about 1,099\%/day and 2,244\%/day; whereas the $\sigma^{\prime \prime} B$. splendens $\mathrm{X}$ o $B$. imbellis hybrids was about $1,113 \%$ /day and $2,531 \% /$ day. This matter was influenced by the female of $B$. imbellis which had dominant variation in length and weight. According to Tave (1993), hybridization was able to repair a productivity due to exploitation of dominant variation.
${ }^{\prime} B$. imbellis $\mathrm{x} \odot B$. splendens hybrids had lower length and weigth growth $(1,099 \pm 0,02 \%$ /day and $2,531 \pm$ $0,13 \% /$ day), than ${ }^{x} B$. splendens $\mathrm{x} \circ \mathrm{B}$. imbellis hybrids $(1,113 \pm 0,04 \% /$ day $)$, whereas the survival rate of $C$ hybrids was higher $(42.19 \pm 11.42 \%)$ than that of $o^{\circ} B$. splendens $\mathrm{x} \propto B$. imbellis hybrids (33.67 $\pm 17.08 \%$ ) (Table 4). It showed that the $\sigma^{\prime \prime} B$. imbellis $\mathrm{x}$ o $B$. splendens hybrids had a better resistance to environmental change.

It showed that the highest mortality occured at the onset of rearing and decreased at the fourth month of rearing, however at the beginning of fifth month increased. The mortality at the onset of rearing was caused by a high adaptation respons, because the seeds were not able to adap with the change of environmental culture. Whereas the mortality at the fifth month of rearing was caused by the stress due to handling at the fourth month, which the seed was

Table 4. The growth of hybrids ( $\mathrm{N}=50$ ind.)

\begin{tabular}{lcc}
\hline \multirow{2}{*}{ Parameters } & \multicolumn{2}{c}{ Crossbreed } \\
\cline { 2 - 3 } & $\mathrm{C}$ & $\mathrm{D}$ \\
\hline Initial length $(\mathrm{mm})$ & $4.14 \pm 0.127$ & $4.14 \pm 0.127$ \\
Final length $(\mathrm{mm})$ & $29.93 \pm 1.33$ & $30.75 \pm 2.02$ \\
Absolute length $(\mathrm{mm})$ & $25.97 \pm 1.33$ & $26.61 \pm 2.02$ \\
Spesific growth of length rate (\%/day) & $1.099 \pm 0.02$ & $1.113 \pm 0.04$ \\
Initial weight (g) & $0.023 \pm 0.004$ & $0.019 \pm 0.002$ \\
Final weight (g) & $0.346 \pm 0.05$ & $0.389 \pm 0.03$ \\
Specific growth rate (SGR) (\%/day) & $2.244 \pm 0.13$ & $2.531 \pm 0.14$ \\
Absolute weight (g) & $0.03229 \pm 0.05$ & $0.03704 \pm 0.04$ \\
Survival rate (\%) & $42.19 \pm 11.42$ & $33.67 \pm 17.08$ \\
\hline
\end{tabular}



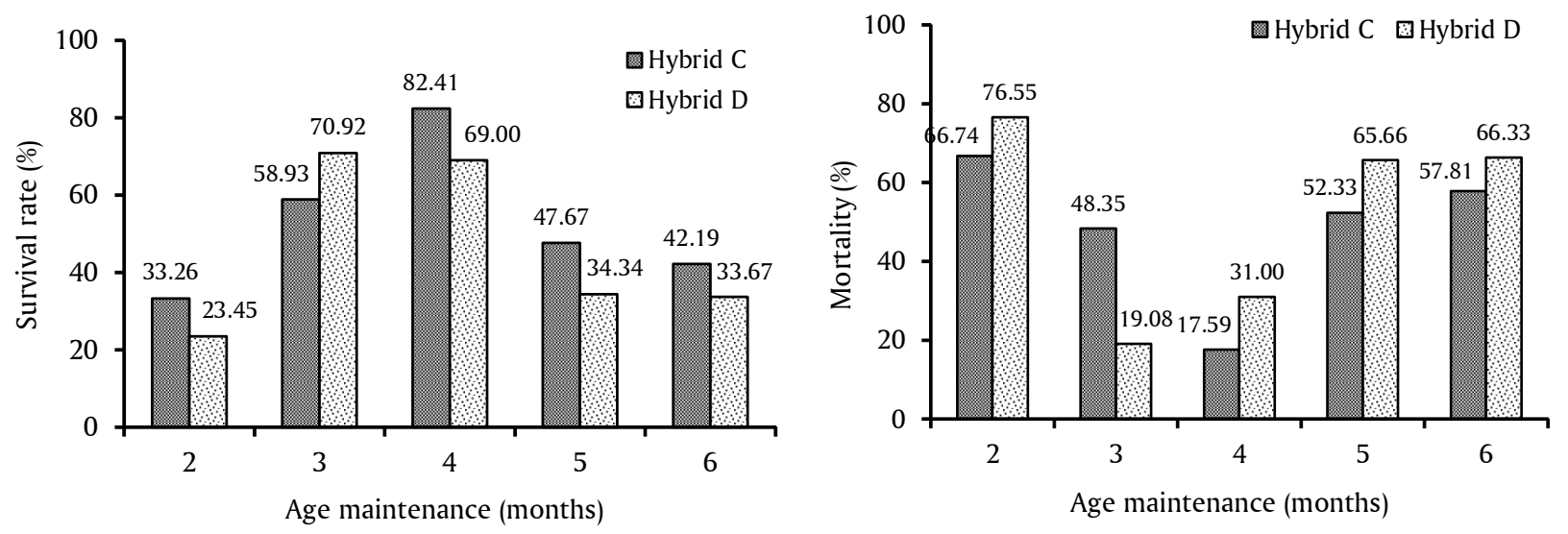

Figure 4. Survival and mortality rate during treatment

transfered solitary, requiring an adaptation in new rearing environment. The hybrids ơ $B$. imbellis $\mathrm{x}$ o $B$. splendens showed a better endurance compared with the hybrids $o^{\prime} B$. splendens $\mathrm{x} \% B$. imbellis, seen by the value of survival rate, namely $42.19 \%$ for ${ }^{\prime \prime} B$. splendens $\mathrm{x} \odot B$. imbellis and $33.67 \%$ for $\sigma^{\prime} B$. splendens $\mathrm{x} \odot B$. imbellis.

\section{The Color Characteristics}

Based on the descriptive color identification on the body, fins, and tie, the hybrids showed 15 color characteristics namely, turquoise, blue, green, white, light-yellow, marble, red, brown, gray, transparant, black, black spot, albino, reddish brown, iridesccent. The marble color was the target with an average $0.22 \%$ ( $\sigma^{\prime} B$. imbellis $\mathrm{x}$ o B. splendens) and $0.16 \%$ ( $\sigma^{*} B$. splendens $\mathrm{x} \&$ $B$. imbellis) from total hybrids per spawning. Color characteristics were produced by a substance that usually was called a pigment, appearing its colored as fish morfology. A pigment is a special feature of body that relies on varied gen and shows the different or same gen action in an individu. (Tave, 1986). The result of descriptive analisys for fenotipe appearance generally resulted 15 characters of color found on the fins, body, and tie (ventral fins). The composition of color generated in every treatment can be seen on the Figure 5.

Based on descriptive color identification the result of hybridization on the whole treatments showed variation of color in the part of fin, ventral, and body. There were 15 types of color on each treatment such as turquoise, red, blue, brown, green, gray, purple, transparant, white, black spot, black, reddish-brown, bright yellow, albino, marble, and the last iridescent. A variation of color that was produced on this hybridization was obtained more color than that of the

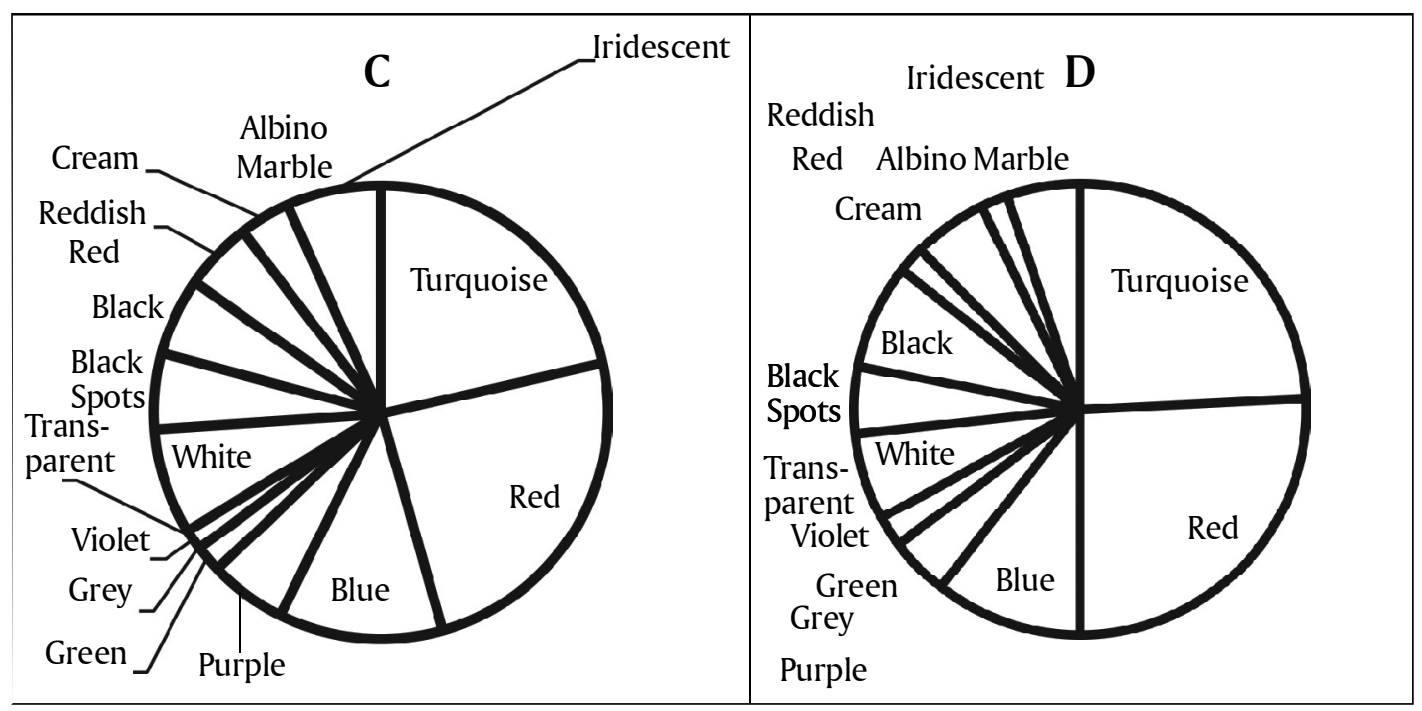

Note: $\mathrm{C}=$ B. imbellis ơ $\mathrm{x}$ B. splendens \%; $\mathrm{D}=$ B. splendens ơ $\mathrm{x}$ B. imbellis o

Figure 5. Color characteristic of crossbreeding wildbetta Betta imbellis vs Betta splendens 
research done by Kusrini (2011) which observed the color pattern of the hybrids of Betta imbellis x Betta splendens. Based on the field studies of the betta breeder that produced marble from the marble broodstock mated with the same type each other on average only got $1 \%-2 \%$. In the other hand after adulthood often mutates into other strains of which belatong and fancy. The marble color was chosen because of the ornamental fish betta color strains that exist from the results of a crossed fellow betta fish aquarium strain was difficult to obtain from each hybridization. Therefore marble strain had a highly value between IDR 350.000,- to 550.000,- per-fish.

The results of color identification determined the strain of hybrids group that included the body, tail fin, dorsal fin, and ventral. It was carried out for each individual as descriptive ways. Color variations on the tail fin, dorsal fin, and anal fin were more numerous than in the tie and the body. In this case the crossed Betta imbellis had the dominant color at its progeny. The color turquoise was a color that was the most widely found on the individual. Colors that appear on the treatment most of the hybrids were scattered on the dorsal fin, anal fin, and tail fin.

A tie in betta fish was one of the body part that can be used to distinguish the betta fish whether they were natural male or female. Natural betta male generally had a long and wide tie; while natural female had short and narrow tie. Based on the Figure 4 , the most individual had a red color on the tie. Red color on the tie was pulled down from color owned by $B$. imbellis. Basic color of body on the natural betta from the observation consists of basic color light (creamy, albino, and marbel) and dark color (reddish brown and black). Moreover, there were also color combination between dark and light with varying proportions.

\section{Color Covering of Fin and Tie ( $\mathrm{N}=50$ ind.)}

Each individual had a different color on the proportions of the fin and tie. Calculation the color cover percentage was done on the body, fins, and tie using descriptive standards based on Indo Betta Club. The proportion of color closure on each of the individual parts is presented in Figure 6, 7, 8, and 9.

On the most color proportions on the dorsal fin was red, which the average closure reached $50 \%$ (half the tail section). Brown was followed with an average of $40 \%$, of turquoise, clear/transparent, and grey with an average closing up to $30 \%$. On the D treatment, fin colors varied with the existence of individuals which have had the tail section was grey, transparent, and white Figure 6.

On the dorsal fin, the color was turquoise dominating with an average closure reaches $40 \%$, red (35\%), blue (30\%), and black spots (25\%). There was a little difference between the dorsal fin and caudal fin, which was on a dominant color and variations. The dorsal fin had black color pattern of dots to thick lines Figure 6.

The proportion of anal fin closure by the red color was also dominated on both treatments as well as on the caudal fin. Average closing red color reached 64\%

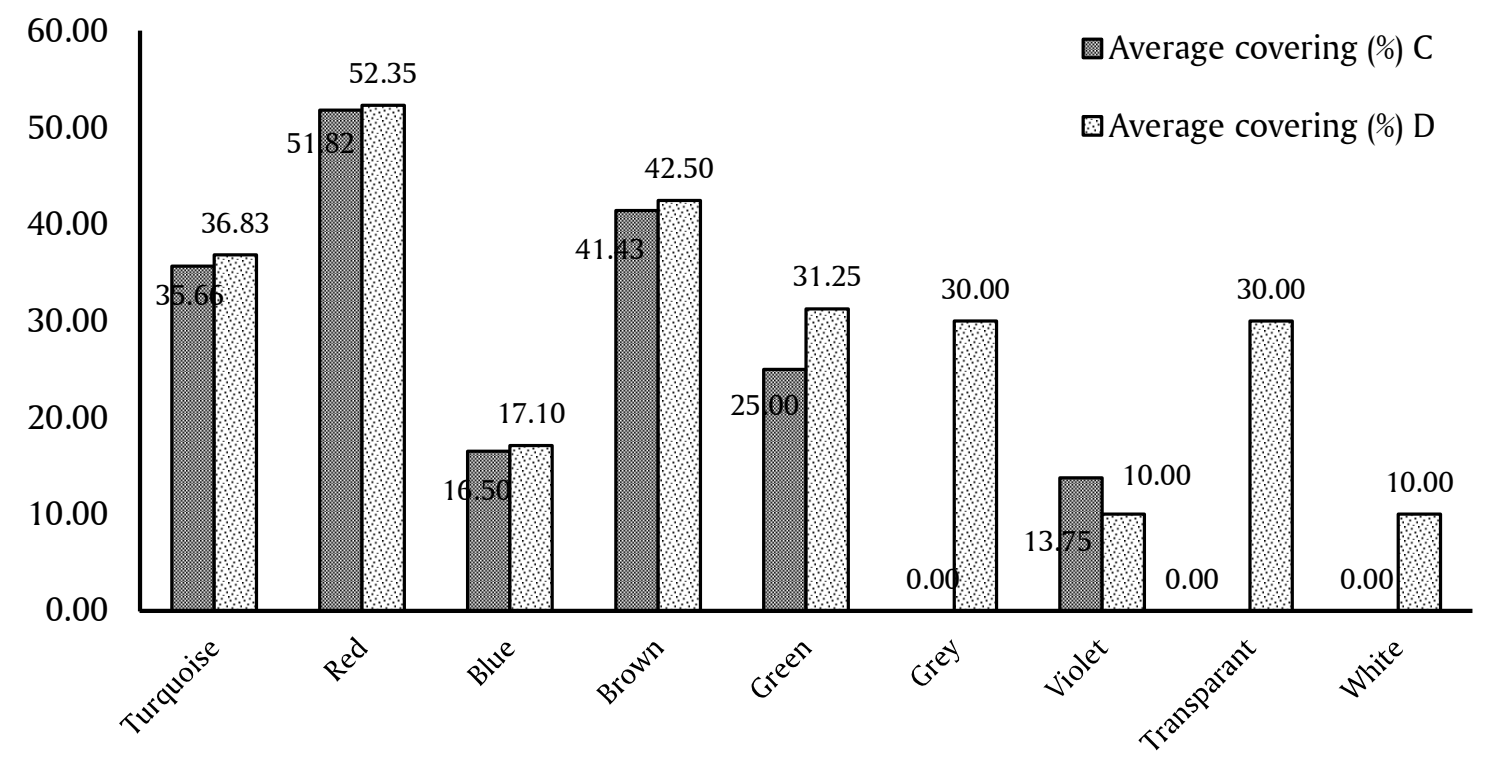

Note: $\mathrm{C}=B$. imbellis ơ $\mathrm{x}$ B.splendens ${ }^{\prime} ; \mathrm{D}=B$. splendens ơ $\mathrm{x}$ B. imbellis $\circ$

Figure 6. Percentage of color covering on caudal fin 


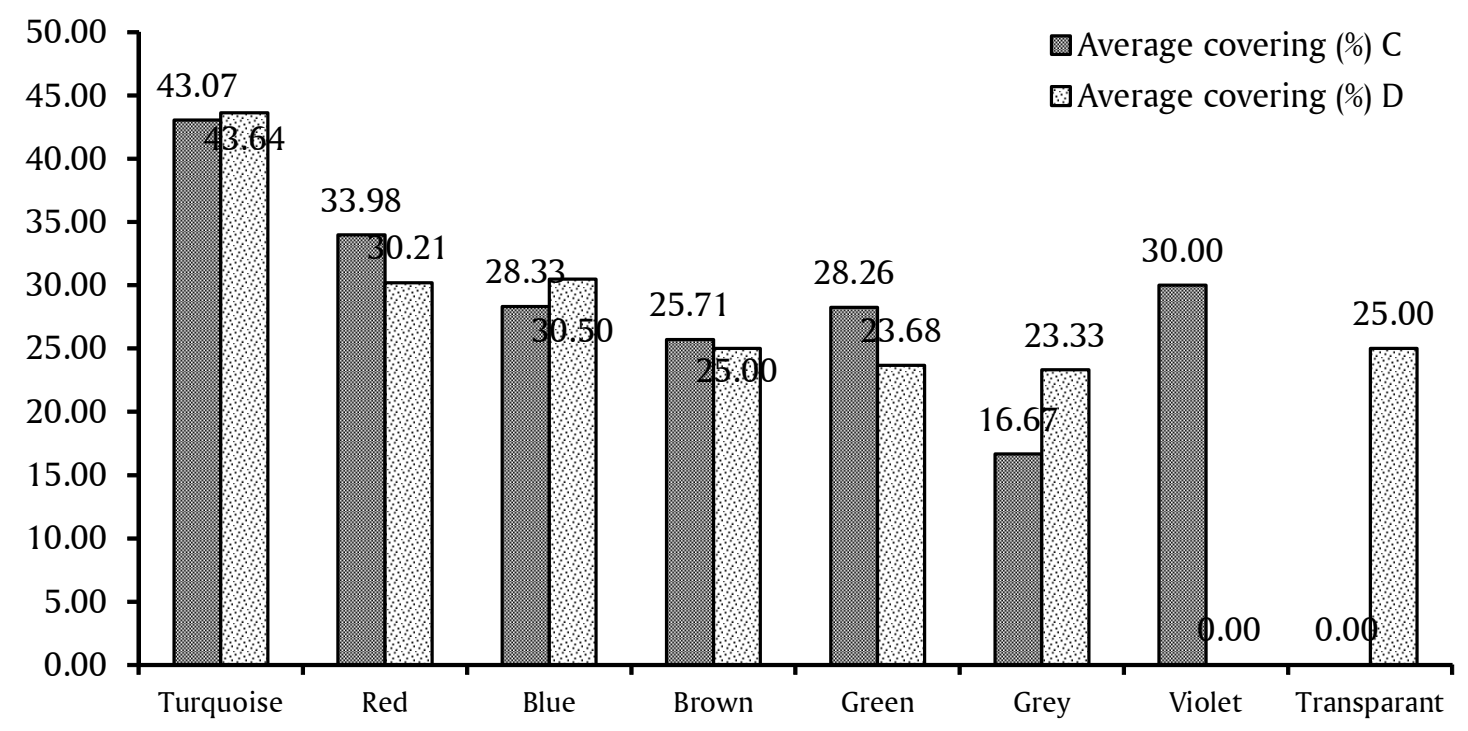

Note: $\mathrm{C}=$ B. imbellis ơ $\mathrm{x}$ B. splendens ○; $\mathrm{D}=$ B. splendens ơ $\mathrm{x}$ B. imbellis $\subsetneq$

Figure 7. Percentage of color covering on dorsal fin $(\mathrm{N}=)$

on the anal fin (Figure 7). The closure of the brown color was on the second-placet, but Brown color was only found on a few individuals.

Color variation in a ventral fin consisted of red, turquoise, blue, brown, black, and white. The closure by the red color dominated for the both treatments, the average closing was $70 \%$, while the closure by the lowest blue color among other colors reached $10 \%$ (Figure 8 ).

\section{The Combination and Composition of Color on the Fin and Tie of Croosbreeding}

Every individual that results in this study had different color combinations on the fin and tie. Color combination was composed from one color to the four different colors with different composition. The dorsal fin had the most color combination that was 19 color. While the anal fin, tail fin, and tie had of 13 , 15 and 17 colors respectively. The color combinations on the fin and tie are presented in Figure 9.

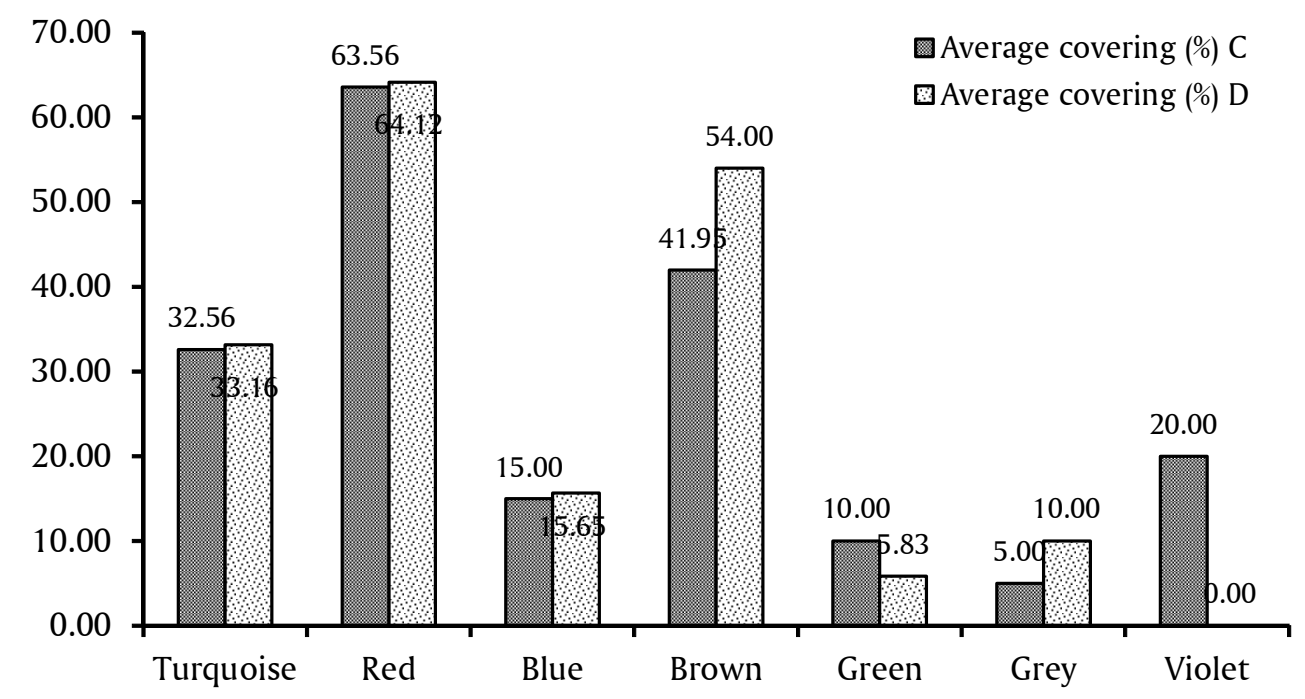

Note: $\mathrm{C}=B$. imbellis ơ $\mathrm{x}$ B. splendens ; $\mathrm{D}=$ B. splendens ơ $\mathrm{x}$ B. imbellis \%

Figure 8. Percentage of color covering on anal fin 


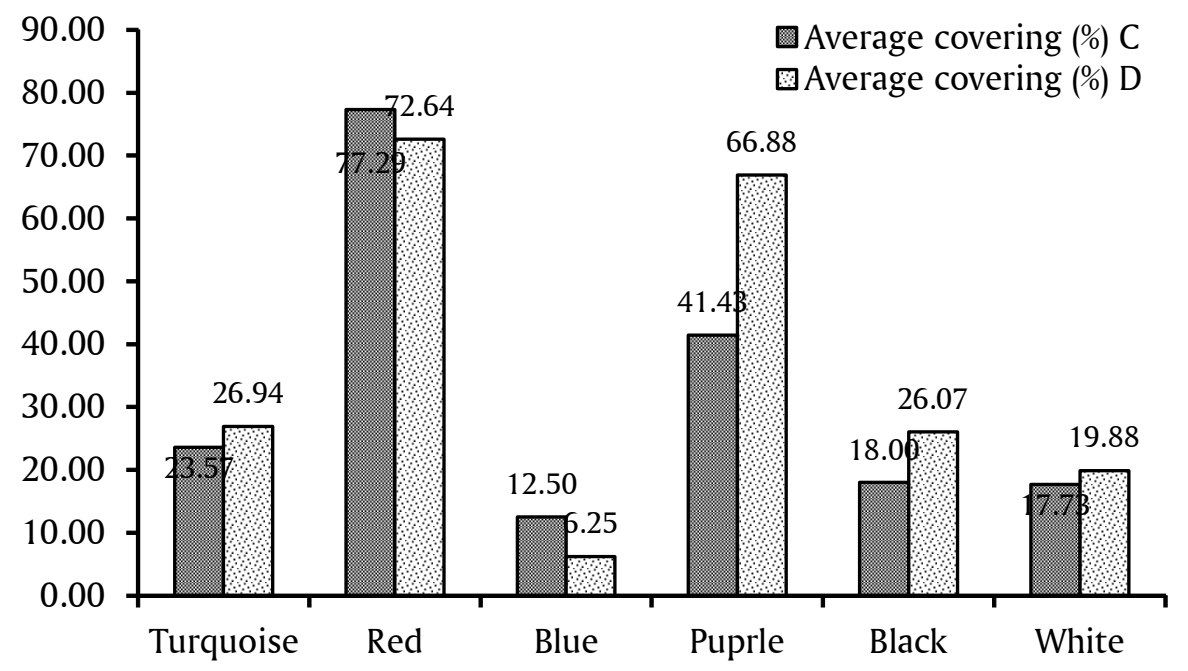

Figure 9. Percentage of color covering on ventral fin

The most combination of dorsal fin colors found on the generation was the TMSB (Turquoise, red, black spot, and blue) as many as 18 individuals, whereas in a caudal fin was the largest combination of TMB (Turquoise, red, and blue) that reached 45 individuals. As on the tail fin, the composition of the anal fin colors was also dominated by the composition of the TMB (Turquoise, red, and blue) that as many as 35 individuals. The tie was somewhat different with the fins. Most color combination on the fins consisted of three colors or more, while the tie was composed of two colors: red and white (42 indi-
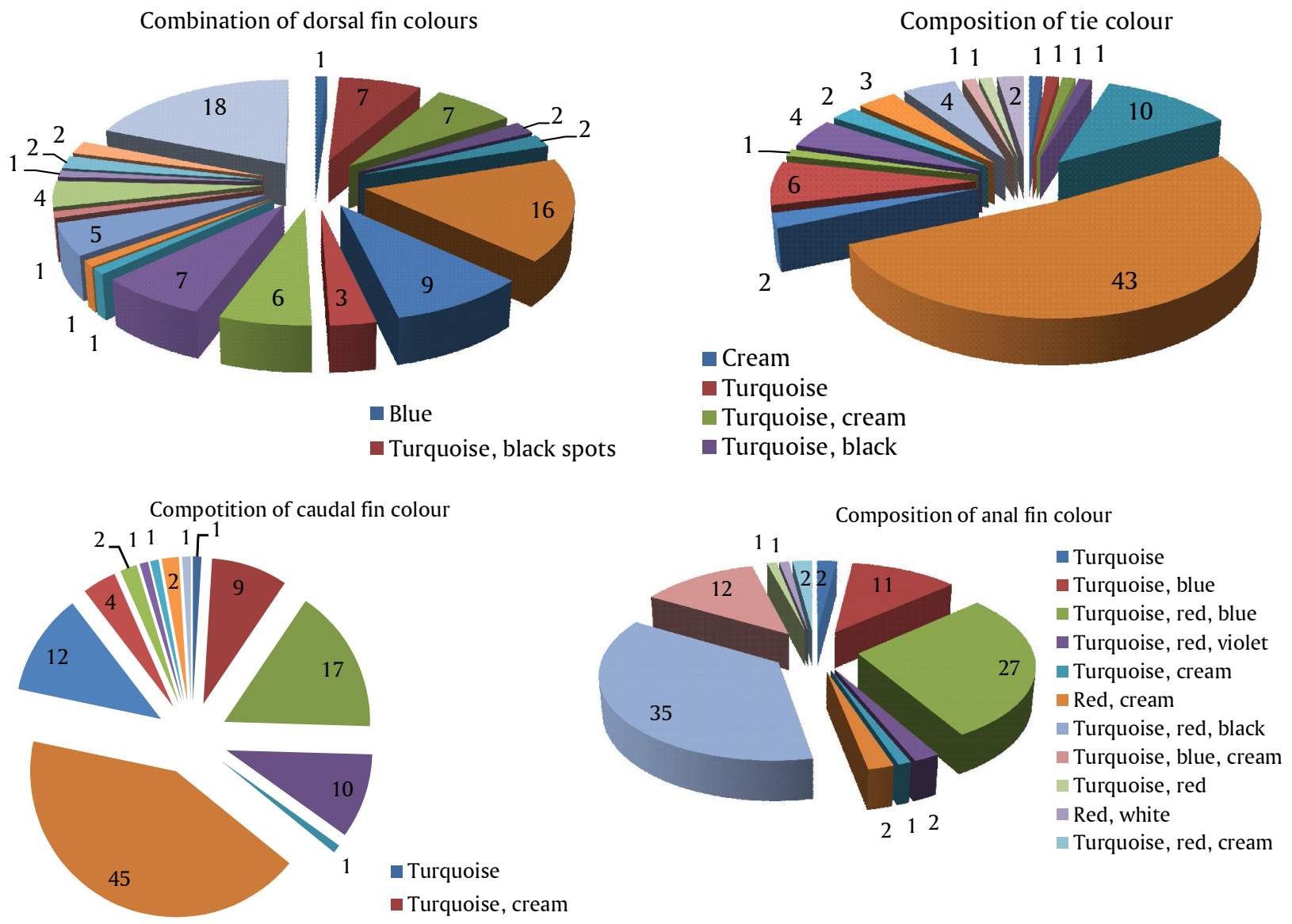

Figure 10. Composition of fin color and the tie 
viduals). Each color on the combination had composition varying from $10 \%$ to $90 \%$.

Generally, a color produced still showed diversity of colors which were seen from many variations of color on the fins, a tie or body, because the wild betta had the phenotype of colors that were complex and hidden on cromatophore. Cromatophore is a special cell for storing or synthesize pigment absorb light or its structure (Leclercq et al., 2009). Types of fish cromatophore based on color pigment were melanophore (black and brown), xantophore (yellow), eritrophore (red), leukophore (white iridofor), and (color reflecting a sheen) (Fuji, 1993); Goda \& Fuji (1995) added the type sianophore that was the bearer brigth blue. Thus the second generation of natural betta hybrid had almost all kinds of cell cromatophore, by different concentration on the fins, the body, and tie.

The diversity of colors appeared with a cross. Both the male and the female broodstock were in the succession of color to his descendants. Gomelsky et al. (1996) in Kusrini et al. (2011) declared that the color segregation in normal offspring (ampimiktik) depends on both the parent, so that it was difficult to determine the value of the contribution of each parent to the offspring. Formation of interesting colors on betta takes place through the mechanism of the movement of pigment caused by a reaction to environmental conditions of the fish. Therefore fish might look different in different environments. Colour pattern or basic colour schemes of fish is fully determined by genetic factors of fish concerned. Appearance of fish color is not only determined by the amount and concentration of the cells also color but also is determined by the depth of the layout of the cells in the skin layers. Color that lies in the skin surface will emit a color that is firm and bright. Chavin (1969) stated that variations color arises because of an absence of variation in concentration a pigment cell, morphology, density, and distribution kromatofor on integument.

\section{Water Quality}

During the maintenance of hybrids there were several parameters monitored namely temperature, $\mathrm{pH}, \mathrm{DO}, \mathrm{NH}_{3}, \mathrm{CO}_{2}$, alkalinity, hardness, and $\mathrm{NO}_{2}$. To keep the balance of water quality, made of $100 \%$ water exchange every week. Terminalia catappa leaves was added to the medium water to stabilize the $\mathrm{pH}$. According to Lesmana (2006), a fish that was kept in its natural color had a brighter color with a slick and shiny scales, the fish color also became assertive and clear. The water quality measurement was still in a range to support the life and the development of fish B. imbeliis and B. splendens and their fry (Table 5).

The measured temperature during maintenance was relatively stable, which ranged from $26.3^{\circ} \mathrm{C}$ $29.1^{\circ} \mathrm{C}$, whereas the $\mathrm{pH}$ was between $6.8-7.59$. According to Hung et al. (2004) in public waters, the appropriate water temperature ranged between $28^{\circ} \mathrm{C}$ $30^{\circ} \mathrm{C}$ and $\mathrm{pH}$ between 7.0-8.0. According to Ferdoushi \& Haque (2006), $\mathrm{pH}$ and temperature values were between $30.06^{\circ} \mathrm{C}-30,13^{\circ} \mathrm{C}$ and $7,12-9,1$. According to Rainboth (1996), pH and temperature which was appropriate for the maintenance of fish Betta splendens ranged between $6-8$ and $24^{\circ} \mathrm{C}-30^{\circ} \mathrm{C}$.

Table 5. Water quality during treatments

\begin{tabular}{lc}
\hline \multicolumn{1}{c}{ Parameters } & Mean \\
\hline Temperature $\left({ }^{\circ} \mathrm{C}\right)$ & $26,3-29,1$ \\
$\mathrm{pH}$ & $6,8-7,59$ \\
$\mathrm{DO}(\mathrm{mg} / \mathrm{L})$ & $4,13-7,23$ \\
$\mathrm{NH}_{3}(\mathrm{mg} / \mathrm{L})$ & $0,001-0,002$ \\
$\mathrm{CO}_{2}(\mathrm{mg} / \mathrm{L})$ & $4-6$ \\
Alkalinity $(\mathrm{mg} / \mathrm{L})$ & $22,66-43,51$ \\
Hardness $(\mathrm{mg} / \mathrm{L})$ & $35,42-46,2$ \\
$\mathrm{NO}_{2}(\mathrm{mg} / \mathrm{L})$ & $0,002-0,04$ \\
\hline
\end{tabular}




\section{CONCLUSION}

The hybrids of $B$. imbellis (o) $x B$. splendens (o') (D) had a specific length and weight rate, $(1,113 \pm 0.04 \% /$ day; $2,531 \pm 0.14 \% /$ day; $26.61 \pm 2.02 \mathrm{~mm}$ ) which was better than that of the hybrids $B$. imbellis $\left(\sigma^{\circ}\right) \times B$. splendens (o) (C) $(1,099 \pm 0.02 \% / \mathrm{day} ; 2,244 \pm 0.13 \% /$ day; $25.97 \pm 1.33 \mathrm{~mm}$ and $0.0027 \pm 0.0003 \mathrm{~mm})$. However, the survival rate of the $C$ hybrids (42.19 \pm $11.42 \%)$ was higher than those of D (33.67\%-17.08\%). Based on the obtained results of the color identification the hybrids had as many as 15 characters of color, homozygous strains of marble which became the target of as much as $1 \%$.

\section{ACKNOWLEDGEMENT}

This research was financed by the aquaculture research program DIPA 2012, Research and Development Institute for Ornamental Fish. A team of researchers would like to thank to those who helped the activities run well, Mr. Joty Atmadjaya (Chairman of the Association of exporters and INBS) along with his colleague, who helped in the search for the prospective broodstock in the nature.

\section{REFERENCES}

Bromage, N.R., Jones, J., Randall, C., Thrush, M., Davies, B., Springate, J., Duston, J., \& Barker, G. (1992). Broodstock management, fecundity, egg quality and the timing of egg production in the rainbow trout (Oncorhynchus mykiss). Aquaculture, 100, 141-166.

Carrillo, M., Bromage, N.R., Zanuy, S., Serrano, R., \& Prat, F. (1989). The effects of modifications in photoperiod on spawning time, ovarian development and egg quality in the sea bass (Dicentrarchus labrax L.). Aquaculture, 81, 351-365.

Castell, J.D., \& Tiews, K. (1980). Report on the standardization of methodology of fish nutrition research. EIFAC Technical Paper, 36, 24.

Chavin, W. (1969). Fundamental aspects of morphological melanin color changes in vertebrate skin. American Zoologist, 9, 505-520.

DEPLU. (2005). Panel discussion "Indonesia marine policy studies in support of development and the national integrity". Directorate of Information and Media, Ministry of Foreign Affairs, Republic of Indonesia. Press Release. DEPLU NO. 41/PR/IV/ 2005.

Effendie, M.I. (1997). Biological methods Fishing. Yayasan Dewi Sri. Bogor, 105 pp.

Ferdoushi, Z., \& Haque, F. (2006). Effect of different stocking ratio of pangasiid catfish (Pangasius hypophthalmus) and silver carp (Hypophthalmicthys molitrix) on better water quality maintenance in catfish farming. Pakistan Journal of Biological Sciences, 9(9), 1732-1737.

Fuji, R. (1993). Cytophysiology of fish chromatophores. International Review of Cytology, 143, 191255.

Gillet, G. (1994). Beyond the orthodox: Heresy in medicine and social science. Social Science \& Medicine, 39, 1125-1131.

Goda, M., \& Fujii, R. (1995). Blue chromatophores in two species of Callionymid fish. Zoological Science, 12,811-813.

Hickling, S. (1968). Fish hibridization. Proc. Of World Symp On Warm Water Pond Fish Culture. FAO Fish Rep., 44, 1-10.

Hung, L.T., Suhenda, N., Slembrouck, J., Lazard, J., \& Moreau, Y. (2004). Comparison of dietary protein and energy utilization in three Asian catfishes (Pangasius bocourti, P. hypophthalmus, and Pangasius djambal). Aquaculture Nutrition, 10, 317-326.

Huynh, M.S., \& Fotedar, R. (2004). Growth, survival, hemolymph osmolality and organosomatic indices of the western king prawn (Penaeus laticulatus Kihinouye, 1896) reared at different salinities. Aquaculture, 234, 601-614.

Ipur. (2012). Most ornamental fish sold in the market www.singkong.web.id. download at 28 October 2012.

Kusrini, E., Kusumah, R.V., Rahmawati, R., Prasetio, A.B., Murniasih, S., Cindelaras, S., \& Sudarto. (2011). Genetic improvement on wild betta (local) with crosses. Final Report of Research, Center for Research and Development of Ornamental Fish Culture. Ministry of Marine Affairs and Fisheries. Jakarta, 18 pp.

Lesmana, D.S. (2006). A bright ornamental fish. Penebar Swadaya. Jakarta, 66 pp.

Leclercq, E., Taylor, J.F., \& Migaud, H. (2009). Morphological skin color changes in teleosts. Fish and Fisheries. Blackwell Publishing.Ltd., 32 pp.

Rainboth, W.J. (1996). FAO species identification field guide for fishery purposes. Fishes of the Cambodian, Mekong. Food and Agriculture Organization of the United Nations. Rome, p. 1-265.

Sakti, I. (2012). Foreign exchange gain of ornamental fish business. www.kkp.go.id. download at 7 October 2012. 2 pp.

Saveedra, C., \& Amat, F. (2005). Maternal effect on encysment in crosses between two geographic strains of Artemia franciscana. Journal of heredity, 96(6), 713-717. 
Tave, D. (1986). Genetics for fish hatchery managers. Tave, D. (1993). Genetics for fish managers. The AVI The AVI Publishing. Company, Inc. America, 299 Publ. Comp. Inc. NY. USA.

pp. 